\title{
Hypoxanthine derivatives in experimental infections
}

\author{
Claudio de simone, MD, Edoardo Arrigoni Martelli, MD, Pietro Foresta, MD, Giuseppe Famularo, MD, \\ Roberto GIACOMELLI, MD, EMILIO JIRILLO, MD, VITO RUgGIERO, PHD, GIORGIO TONIETI, MD
}

\begin{abstract}
C De Simone, EA Martell, P Foresta, et al. Hypoxanthine derivatives in experimental infections. Can J Infect Dis 1992;3(Supp1 B):106B-110B. In vivo treatment with parenterally administered hypoxanthine derivatives, notably ST 789, was able to protect cyclophosphamide-immunosuppressed mice against experimental infections with both bacterial and fungal pathogens. However, the mechanisms accounting for these effects of hypoxanthine derivatives remain to be fully established. In fact, only the treatment with ST 789 resulted in a clear enhancement of the primary antibody production as well as macrophage phagocytic activity, whereas $T$ lymphocyte responsiveness to mitogens and both macrophage- and natural killer-dependent cytotoxicity were not significantly affected. These data, together with the recently shown ability of ST 789 to increase interleukin-6 production, suggest that monocyte/macrophages are likely to be the main cellular target of the immunomodulating activity of ST 789. Finally, in the present in vivo study, hypoxanthine derivatives did not enhance the mean survival time of tumour-bearing immunosuppressed mice.
\end{abstract}

Key Words: Experimental infections, Hypoxanthine derivatives, ST 789

\section{Dérives de l'hypoxanthine dans les infections expérimentales}

Le traitement in vive à l'aide de dérivés de l'hypoxanthine administrés par voie parentérale, notamment le ST 789, a réussi à protéger des souris immunosupprimées à la cyclophosphamide contre les înfections expérimentales, tant bactériennes que fongiques. Cependant, les mécanismes responsables des effets des dêrivés de l'hypoxanthine demeurent méconnus. En fait, seul le traitement avec le ST 789 a donné lieu à une nette amélioration de la production d'anticorps primaires et de l'activité phagocytaire sur les macrophages, alors que la réactivité des lymphocytes $\mathrm{T}$ aux mitogènes et la cytotoxicité liée tant aux macrophages qu'aux cellules tueuses naturelles n'ont pas été significativement affectées. Ces données, ainsi que la capacité récemment démontrée du ST 789 à augmenter la production d'interleukine-6 suggèrent que les monocytes/macrophages sont susceptibles d'être la cible cellulaire principale de l'activité immunomodulatrice du ST 789. Finalement, dans la présente étude in vivo, les dérivés de l'hypoxanthine n'ont pas amélioré le temps de survie moyen des souris immunosupprimées porteuses d'une tumeur.

Infectious Diseases and Internal Medicine, L'Aquila; Sigma Tau, Pomezia; and Immunology. Bari, Italy

Correspondence and reprints: Dr Giuseppe Famularo, Department of Internal Medicine, Via S Sisto, 67100, L'Aquila, Italy. Telephone (0039) 862-433401, Fax (0039) 862-433383 
$S^{\prime}$ EVERAL RECENT REPORTS SUGGESTED THAT ARGININE AND arginine-containing hypoxanthine derivatives can strongly modulate immune functions both in vitro $(1,2)$ and in vivo (1,3-5). ST 789, which has a pentyloxycarbonil-L-arginine residue at the N-9 position of the hypoxanthine ring, strongly enhanced in vitro interleukin-6 (IL-6) production by mitogen-driven peripheral blood mononuclear cells (6) as well as T lymphocyte responsiveness to mitogens $(7,8)$ and natural killer- and macrophage-dependent cytotoxicity $(1,4,5,9)$. Furthermore, cyclophosphamide-immunosuppressed mice injected with ST 789 were more resistant to experimental infections from both bacterial and fungal pathogens $(10,11)$.

Several arginine-containing hypoxanthine derivatives are currently available. The main difference between ST 789 and its derivatives is that the derivatives, instead of having a terminal L-arg aminoacidic residue, possess an L-arg terminal peptide of varying length (two to five aminoacidic residues). However, reports evaluating both in vitro and in vivo immunomodulating properties of the derivatives are currently lacking. In contrast, ST 789 has been evaluated extensively in this respect. The present study found that, as a group, hypoxanthine derivatives other than ST 789 are not very potent immune modulators. However, after treatment with many hypoxanthine derivatives (including ST 789) experimentally infected mice were protected against challenge with several pathogens. Finally, while ST 789 had some antitumour activity, the other derivatives evaluated did not.

\section{MATERIALS AND METHODS}

Hypoxanthine derivatives: ST 789 , ST 848 , ST 872 , ST 873 , ST 897 , ST 657 , ST 733 , ST 742 , ST 754 , ST 785 and ST 786, purchased from Sigma-Tau (Pomezia, Italy), were studied.

Experimental infections: Seven- to 10-week-old CD1 male mice and 12- to 16-week-old female Balb/c mice were used. Klebsiella oxytoca $552\left(5 \times 10^{3}\right.$ and $\left.3.5 \times 10^{4}\right)$, K pneumoniae $7823\left(1.6 \times 10^{6}\right.$ and $\left.1 \times 10^{7}\right)$, Escherichia coli ISM $\left(1.3 \times 10^{6}\right)$, Serratia marcescens A/ $1\left(3.5 \times 10^{4}\right)$, Salmonella typhimurium $\left(8.5 \times 10^{2}\right)$, Proteus mirabilis $\left(5 \times 10^{3}\right)$ and Pseudomonas aeruginosa $\left(1 \times 10^{10}\right)$ were inoculated intraperitoneally, and Candida albicans $\left(5 \times 10^{5}\right)$ and Aspergillus fumigatus $\left(5 \times 10^{6}\right)$ were inoculated intravenously in cyclophosphamide-immunosuppressed mice. Cyclophosphamide was administered intraperitoneally at dosages ranging from 50 to $150 \mathrm{mg} /$ $\mathrm{kg}$ five days before the induction of infection and approximately $2 \mathrm{~h}$ before starting hypoxanthine derivative treatment, which was given for five consecutive days. In the $P$ aeruginosa model cyclophosphamide was administered two days prior to challenge. As previously reported $(12,13)$, host resistance to infections was estimated by the number of mice surviving after five to 15 days of observation, as well as by the mean survival time.

The protective effects of combined treatment with ST 789 and ceftazidime, and ST 789 and amphotericin B were also evaluated in cyclophosphamide-treated mice challenged with $K$ oxytoca and $C$ albicans, respectively. Ceftazidime and amphotericin B were administered at per se completely ineffective dosages ranging from 0.02 to $2.0 \mathrm{mg} / \mathrm{kg}$ and 1.0 to $2.5 \mathrm{mg} / \mathrm{kg}$, respectively.

The statistical analysis of results was performed using Fisher's test and $\chi^{2}$ test.

Primary antibody production: $\mathrm{B}_{6} \mathrm{D}_{2} \mathrm{~F}_{1}$ mice lage six weeks) were administered hypoxanthine derivatives intraperitoneally at either $0.25,2.5$ or $25 \mathrm{mg} / \mathrm{kg}$ per day for five days. On day 3 , mice were injected with $1 \times 10^{7}$ sheep erythrocytes in $0.2 \mathrm{~mL}$. Spleen cells obtained from mice immediately following death were adjusted at a density of $1 \times 10^{7}$ cells $/ \mathrm{mL}$ in Iscoves' modified Dulbecco's medium (IMDM; Gibco, New York) supplemented with fetal calf serum, $5 \times 10^{-5} \mathrm{M} 2$-mercaptoethanol, 4\% polyethylene glycol (MEG; Serva, Germany) (molecular weight $6000 \mathrm{Da}$ ) and $50 \mathrm{U} / \mathrm{mL}$ of both penicillin and streptomycin. Antigen was added in the form of $2 \mathrm{~mL} \mathrm{10 \%} \mathrm{sheep} \mathrm{red} \mathrm{blood} \mathrm{cells} / \mathrm{mL}$ of culture. Control cultures without antigen were set up in several experiments. The cultures were incubated at $37^{\circ} \mathrm{C}$ in $5 \%$ carbon dioxide for 90 mins. The cells were washed, resuspended in medium and assayed for plaque-forming cells by using the previously described slide modification of the hemolysis in gel method (14).

T lymphocyte proliferation to mitogens: $\mathrm{T}$ lymphocyte proliferative responsiveness to mitogens was assayed as previously described (15). Spleen cells were obtained from mice given five days of therapy with hypoxanthine derivatives.

Delayed $\mathbf{T}$ hypersensitivity reactions: Delayed $\mathrm{T}$ hypersensitivity reactions were assayed as previously reported (16).

Macrophage-dependent cytotoxicty: Peritoneal exudate cells were obtained by washing the abdominal cavity of $\mathrm{B}_{6} \mathrm{D}_{2} \mathrm{~F}_{1}$ mice with RPMI 1640 . Harvested cells, were centrifuged at $400 \mathrm{~g}$ for $10 \mathrm{mins}$ at $4^{\circ} \mathrm{C}$ and density adjusted to $2 \times 10^{6}$ cells $/ \mathrm{mL}$. Daudi cells were used as target cells. The cytotoxicity test was performed as previously described (5).

Phagocytic activity: The phagocytic activity of peritoneal exudate cells was assayed as previously reported (17). Briefly, peritoneal exudate cells were adjusted to a density of $4 \times 10^{6}$ cells $/ \mathrm{mL}$ to which was added sheep red bloods cells previously opsonized with anti-sheep erythrocyte immunoglobulins. After $1 \mathrm{~h}$ incubation at $37^{\circ} \mathrm{C}$ in $5 \%$ carbon dioxide, nonphagocytosed erythrocytes were removed using hypotonic saline solution.

Natural killer cell-dependent cytotoxicity: The assay of natural killer cell activity was performed using standard methods (18).

Antitumoral activity: Antitumoral activity was assayed as previously described (19). Briefly, inbred C57B1/6 (age eight weeks) and DBA/2 (age six weeks) male mice were used in the experiments with both carcinoma and leukemia models. Outbred CD1 male 
TABLE 1

Protective effects of ST 789 in cyclophosphamide-immunosuppressed mice infected with Klebsiella oxytoca 552

\begin{tabular}{lcc}
\hline $\begin{array}{l}\text { Treatment } \\
\text { (mg/kg/day) }\end{array}$ & $\begin{array}{c}\text { Number of deaths/total number of } \\
\text { animals tested }(\%)\end{array}$ \\
\hline Controls & $5 \times 10^{3}$ bacteria & $3.5 \times 10^{4}$ bacteria \\
Controls & $9 / 143(6.3)$ & $32 / 69(46.4)$ \\
$\quad$ (immunosuppressed) & $90 / 153(58.8)$ & $52 / 70(74.3)$ \\
ST 789 (0.2) & $4 / 60(6.7)^{* *}$ & $17 / 40(42.5)^{*}$ \\
ST 789 (2) & $1 / 25(4.0)^{* *}$ & $2 / 20(10.0)^{* *}$ \\
ST 789 (25) & $6 / 108(5.6)^{* *}$ & $10 / 50(20.0)^{* *}$ \\
\hline
\end{tabular}

ST 789 administered daily by intraperitoneal injection for five consecutive days $2 \mathrm{~h}$ after cyclophosphamide immunosuppression. Mice were in fected 24 h after the last ST 789 administration. ${ }^{*}<<0.05 ; " * P<0.001$ ( $\chi^{2}$ test)

mice (age six weeks) were used in the experiments for sarcoma model. Lewis lung carcinoma cells were injected at a density of $1 \times 10^{5}$ cells $/ \mathrm{mL}$ in $0.1 \mathrm{~mL}$ TC 199 medium; P388 and P1210 leukemia cell lines were injected intraperitoneally at a density of $1 \times 10^{5}$ cells $/ \mathrm{mL}$ in $0.1 \mathrm{~mL}$ of Hank's medium; 180 sarcoma was injected intraperitoneally at a density of $1 \times 10^{3}$ cells $/ \mathrm{mL}$ in 0.1 $\mathrm{mL}$ Hank's medium. The injections were performed on day zero. Hypoxanthine derivatives were administered intraperitoneally at concentrations of 0.25 and 25 $\mathrm{mg} / \mathrm{kg}$ per day, respectively, throughout days 1 to 10 in leukemia- and sarcoma-bearing animals, whereas in Lewis lung carcinoma model the drugs were administered on days 1 to 20 .

The statistical analysis of differences in mean survival time was performed by using the Mann-Whitney $\mathrm{U}$ test.

\section{RESULTS}

Experimental infections: All hypoxanthine derivatives tested were able to protect cyclophosphamide-treated mice against experimental infections with both bacterial and fungal pathogens as shown by improvement in both percentage mortality and mean survival time. In the $K$ oxytoca, $\mathrm{S}$ marcescens and $\mathrm{S}$ typhimurium infective models, ST 789 was most effective when administered intraperitoneally, as it proved active at concentrations as low as $0.25 \mathrm{mg} / \mathrm{kg}$ (Tables 1,2). Similar results were obtained in K pneumoniae, E coli and Ps mirabilis models (data not shown).

In contrast, subcutaneous administrations of the immunomodulator were able to protect mice against only $P$ aeruginos $a$ and $C$ albicans infections, the former occurring when ST 789 was administered alone or in the association with gentamicin (data not shown), and the latter occurring when ST 789 was combined with an 'ineffective' dosage of amphotericin B (Table 3). Oral ST 789 administration was completely ineffective.

Dosages per se completely ineffective of ST 789 and ceftazidime significantly protected, in terms of survival, immunosuppressed mice from experimental infection
TABLE 2

Protective effects of ST 789 in cyclophosphamideimmunosuppressed mice infected with Serratia marcescens $\mathrm{A} / 1$ and Salmonella typhimurium

\begin{tabular}{lcc}
\hline & $\begin{array}{c}\text { Number of deaths/total number of } \\
\text { animals tested }(\%)\end{array}$ \\
$\begin{array}{l}\text { Treatment } \\
\text { (mg/kg/day) }\end{array}$ & $\begin{array}{c}3.5 \times 10^{4} \\
8.5 \times 10^{2}\end{array}$ \\
\hline Controls & $6 / 20(30)$ & $3 / 20(15)$ \\
Controls (immuno- & $16 / 20(80)$ & $11 / 20(55)$ \\
suppressed) & N typhimurium \\
ST 789 (0.25) & ND & $1 / 10(10)^{*}$ \\
ST 789 (25) & $10 / 20(50)^{*}$ & $3 / 20(15)^{* *}$ \\
\hline
\end{tabular}

ST 789 administered daily by intraperitoneal injection for five consecutive days $2 \mathrm{~h}$ after cyclophosphamide immunosuppression. Mice were infected $24 \mathrm{~h}$ after the last ST 789 administration. ND Not done ${ }^{*} P<0.05$; "*P<0.01 (Fisher's test)

\section{TABLE 3}

Protective effects of combined treatment with ST 789 and amphotericin B in cyclophosphamide-immunosuppressed mice challenged with Candida albicans

\begin{tabular}{lcc}
\hline $\begin{array}{l}\text { ST } 789 \\
(\mathrm{mg} / \mathrm{kg} / \text { day })\end{array}$ & $\begin{array}{c}\text { Amphotericin B } \\
(\mathrm{mg} / \mathrm{kg})\end{array}$ & $\begin{array}{c}\text { Number of deaths/ } \\
\text { total number of } \\
\text { animals tested }(\%)\end{array}$ \\
\hline Control* $^{*}$ & 0 & $15 / 15(100)$ \\
0 & 1 & $7 / 7(100)$ \\
0 & 2.5 & $9 / 9(100)$ \\
50 & 1 & $1 / 10(10)^{* *}$ \\
50 & 2.5 & $2 / 10(20)^{* *}$ \\
\hline
\end{tabular}

ST 789 administered subcutaneously daily, five days prior to infection. Amphotericin B administered by single intraperitoneal injection two days after infection. "Untreated, cyclophosphamide-immunosuppressed $\left(150 \mathrm{mg} / \mathrm{kg}\right.$ ) five days before infection) mice infected with $5 \times 10^{3} \mathrm{C}$ albicans cells. " $P<0.001$ (Fisher's test)

\section{TABLE 4}

Protective effects of combined treatment with ST 789 and ceftazidime in cyclophosphamide-immunosuppressed mice challenged with Klebsiella oxytoca 552

\begin{tabular}{lcc}
\hline $\begin{array}{l}\text { ST } 789 \\
(\mathrm{mg} / \mathrm{kg} / \text { day })\end{array}$ & $\begin{array}{c}\text { Ceftazidime } \\
(\mathrm{mg} / \mathrm{kg})\end{array}$ & $\begin{array}{c}\text { Number of deaths/ } \\
\text { total number of } \\
\text { animals tested }(\%)\end{array}$ \\
\hline Control & 0 & $8 / 10(80)$ \\
0.05 & 0 & $8 / 10(80)$ \\
Control & 0.02 & $9 / 10(90)$ \\
Control & 0.2 & $2 / 10(20)$ \\
Control & 2.0 & $0 / 10(0)$ \\
0.05 & 0.02 & $3 / 10(30)^{*}$ \\
0.05 & 0.2 & $0 / 10(0)$ \\
0.05 & 2.0 & $0 / 10(0)$ \\
\hline
\end{tabular}

ST 789 administered intraperitoneally daily five days prior to infection. Ceftazidime administered intraperitoneally $1 \mathrm{~h}$ after infection. Control Untreated, cyclophosphamide-immunosuppressed (100 mg/kg five days before infection) mice infected with $3.5 \times 10^{4} \mathrm{~K}$ oxytoca cells. " $\mathrm{P}<0.05$ (Fisher's test)

with $K$ oxytoca (Table 4). The same was true in the $A$ fumigatus model since ST 789 and amphotericin B administered at dosages per se ineffective were synergistic (data not shown). 
Primary antibody production: A significant increase in the number of plaque-forming cells was found in mice administered with ST 657 at dosages of 2.5 and 25 $\mathrm{mg} / \mathrm{kg}$. ST 789 resulted in a strong increase of plaqueforming cells when administered only at $25 \mathrm{mg} / \mathrm{kg}$. On the other hand, both ST 783 and ST 733 resulted in a significant decrease in the number of plaque-forming cells (data not shown). Finally, ST 848, ST 872, ST 897, ST 742 , ST 754 , ST 785 and ST 786 did not significantly affect the number of plaque-forming cells.

T lymphocyte responsiveness to mitogens: None of the hypoxanthine derivatives affected lymphocyte proliferation following stimulation with mitogens, such as phytohemagglutinin, lipopolysaccharide and concanavalin A. A slight but not significant reduction of mitogendriven lymphocyte proliferation was found in mice administered ST 657. Overall, these data support previous experiments performed in the authors' laboratory indicating that ST 789 is not able to enhance in vitro the surface expression of activation antigens, such as IL-2 and transferrin receptors, as well as IL-2 and interferongamma production by phytohemagglutinin-stimulated peripheral blood mononuclear cells $(6,20)$.

Delayed T cell hyperreactivity reactions: None of the hypoxanthine derivatives investigated significantly affected delayed $\mathrm{T}$ cell hyperreactivity reactions.

Macrophage-dependent cytotoxicity: Treatment with hypoxanthine derivatives did not result in any significant change of macrophage cytotoxicity.

Phagocytic activity of peritoneal exudate cells: ST 789 strongly increased the phagocytic capacity of peritoneal exudate cells, as demonstrated by the increased number of phagocytozed sheep erythrocytes per single cell as well as per 100 exudate cells (data not shown). However, the percentage of macrophages was not affected by administering ST 789. ST 657, ST 733, ST 754 and ST 785 were not as effective as ST 789 in enhancing phagocytosis.

Natural killer cell-dependent cytotoxicity: ST 789 administration resulted in a slight reduction of natural killer cell cytotoxicity. However, natural killer cell activity was not affected by administering hypoxanthine derivatives other than ST 789 (data not shown).

Antitumour activity: In these experimental models, hypoxanthine derivatives did not exert any antitumour activity, demonstrated by the inability to detect any increase in mean survival time of tumour-bearing mice following in vivo treatment (data not shown).

\section{DISCUSSION}

The results clearly show that hypoxanthine derivatives, most notably ST 789, exhibit immunomodulating properties. In fact, this group of molecules protected cyclophosphamide-immunosuppressed mice against experimental infections with bacterial and fungal pathogens, confirming previous reports $(10,11)$. Furthermore, the combined administration of ST 789 and antimicrobial agents, such as ceftazidime, amphotericin B and gentamicin, at doses per se completely ineffective, strongly protected cyclosphosphamidetreated mice in several models of experimental infections. Therefore, ST 789 either alone or in combination with antibiotics enhances host resistance to pathogens.

The mechanisms responsible for these effects of hypoxanthine derivatives are unclear. The reported ability of ST 789 to restore mitogen responsiveness of lymphocytes from cyclophosphamide-treated mice is likely to play a major role (21). However, other cells could mediate the immunomodulating activity of ST 789. In fact, ST 789 treatment expanded bone marrow natural killer progenitor cells in vivo, thus strongly enhancing the regeneration of mouse natural killer cell activity (9). Furthermore, as cyclophosphamide treatment severely reduces the number of circulating granulocytes (22), the capacity of hypoxanthine derivatives to protect cyclophosphamide-administered mice against pathogens might - at least in part - depend on their myelorestorative ability. However, a role for colony stimulating factors in mediating the immunomodulation of hypoxanthine derivatives is still unproven.

Data from the authors' laboratory showing an increased in vitro production of IL- 6 by peripheral blood mononuclear cells cultured in the presence of both mitogens and ST 789 compared with control cultures suggest that hypoxanthine derivatives could act in vivo by modulating cytokine production (6). Furthermore, the present report shows that in vivo administered ST 789 , as well as other hypoxanthine derivatives, strongly enhanced the phagocytic activity of peritoneal exudate macrophages. Since macrophages are the main cellular source of IL-6 (23) this suggests that hypoxanthine derivatives exert an action on monocytes/macrophages. Overall, these findings suggest that hypoxanthine derivatives could modulate infections with intracellular pathogens such as listeria, legionella, brucella, salmonella and mycobacteria.

A temporal relationship in cytokine production has been recently demonstrated for tumour necrosis factor, IL- 1 and IL-6 production (24). After a bacterial challenge, the appearance of IL- 6 follows that of tumour necrosis factor and IL-2 during endotoxemia $(25,26)$. Thus, the most likely scheme of activation leading to cytokine production involves the early release of tumour necrosis factor and IL-1 from monocytes/macrophages which subsequently induces the secretion of IL-6 and other cytokines from both monocytes and structural cells, such as fibroblasts and endothelial cells. This cascade is the basis for the finding of sequential elevations of cytokines in plasma in experimental models of inflammation (25-27).

The role of tumour necrosis factor in mediating the ST 789-dependent increase of IL-6 production remains to be established. Furthermore, there is no report on the ability of hypoxanthine derivatives other than ST 
789 to modulate cytokine release in vivo or in vitro. In this study, these compounds exhibited immunomodulating activity in vivo. However, the in vitro lymphocyte responsiveness to mitogens, natural killer cell activity and delayed $\mathrm{T}$ cell hyperreactivity reactions were not significantly affected. Only ST 789 was able to increase the primary in vitro antibody production compared with other hypoxanthine derivatives, possibly by increasing IL-6 production (6). Therefore, the mechanisms involved in determining enhanced host resistance by hypoxanthine derivatives are still unresolved.

Finally, in the present study hypoxanthine derivatives did not show any in vivo antitumour activity. The results are in contradiction with previous reports in-

\section{REFERENCES}

1. Reynolds JV, Daly JM, Zhang SM, Ziegler MM, Nasi A. Arginine, protein malnutrition and cancer. J Surg Res 1988;45:513-22.

2. Fabris N, Moccheggiani E. Arginine-containing compounds and thymic endocrine activity. Thymus 1992;19:521-30.

3. Reynolds JV, Daly JM, Shou J, Sigal R, Ziegler MM, Naji A. Immunological effects of arginine supplementation in tumor-bearing and non tumor-bearing hosts. Ann Surg 1990:211:202-10.

4. Lowell JA, Parnes HL, Blackborn GL. Dietary immunomodulation: Beneficial effects on oncogenesis and tumor growth. Crit Care Med 1990;18:145-8.

5. Daly JM, Reynolds JV, Thon AK, et al. Immune and metabolic effects of arginine in the surgical patient. Am Surg 1988;208:512-33.

6. Famularo G, Giacomelli R, Valdarnini D, De Simone C, Tonietti G. Modulation by ST 789 of 'in vitro' lymphocyte activation and cytokine production. Thymus 1992;19:571-8.

7. Giovarelli M, Arione R, Jemma C, et al. In vitro and in vivo immunomodulatory activity of a N-9 arginyl hypoxanthine derivative (PCF-39). Int $\mathrm{J}$ Immunopharmacol 1987:9:659-67.

8. Baldinelli L, Biselli R, Fattorossi A. Influence of ST 789 on murine thymocytes: A flow cytometry study of thymocyte subset distribution and of intracellular free $\mathrm{Ca}^{++}$increase upon activation. Thymus 1992;19:552-61.

9. Riccardi C, Migliorati G. Enhancement of murine NK cell activity generation by ST 789. Thymus 1992;19:509-12.

10. Foresta P, Riccardi C. Immunorestorative properties of ST 789 on experimentaly immunosuppressed and infected mice. Thymus 1992;19:597-608.

11. De Simone C, Arrigoni Martelli E, Famularo G, Giacomelli R, Jirillo E, Tonietti G. ST 789, a candidate for combination therapies of infections and cancer. In: Goldstein AL, Garaci E, eds. Proceedings of the First International Symposium on Combination Therapies. New York: Plenum Publishing Corp 1992:223-9.

12. Fauchère JL, Simonet M, Meirleire F, Verona M. Effet des immunodepresseurs sur l'activité dela ticarcilline chez le souris infectée par P aeruginosa. Ann Microbiol (Institut Pasteur) 1981;132B:215-24.

13. Tamura Y, Tanaka S. Effect of cyclophosphamide on experimental infection of mice with Clostridium chauvoei. Jpn J Vet Sci 1983;45:825-7.

14. Luzzati AL. Induction of an antibody production in cultures of human peripheral blood lymphocytes. In: dicating that mice injected with ST 789 exhibited significant resistance against two synergistic tumours (7). Furthermore, the arginine residue of ST 789 has been suggested to play a pivotal role in mediating the antitumour activity of ST 789 by increasing T lymphocyte cytotoxicity $(3,4)$ as well as natural killer cell and macrophage cytotoxicity (3-5). The enhancement of $\mathrm{T}$ helper function could also be involved, as suggested by the absolute increase of CD4+ T cells observed in cancer patients following treatment with arginine-lysine combination (unpublished data). The inability to find any increase in mean survival time of tumour-bearing mice following in vivo administration of hypoxanthine derivatives may be related to peculiarities of the experimental protocol.

Lefkovits I, Pernis B, eds. Immunological Methods.

London, New York: Academic Press 1981:241-53.

15. Guidi L, Specter S, Bartoloni C, Phuphanic S, Prockop $\mathrm{LD}$, Friedman $\mathrm{H}$. Inibitory activity on IL-2 production and response of serum from cancer patients. EOS J Immunol Immunopharmacol 1990;10:22-7.

16. Miller TE, Mackaness GB, Lagrange PH. Immunopotentiation with BCG. Modulation of the response to sheep red blood cells. J Natl Cancer Inst 1973;51:1669.

17. Williams CA, Chase MW. Methods in Immunology and Immunochemistry, vol 5. New York: Academic Press, 1976:261-3.

18. Grazia Cifone M, Giacomelli R, Famularo G, et al. Natural killer activity and antibody-dependent cellular cytotoxicity in progressive systemic sclerosis. Clin Exp Immunol 1990;80:360-5.

19. Sirotnak FM, Moccio DM, Dorick DM. Optimization of high-dose methotrexate with leucovorin rescue therapy in the L1210 leukemia and sarcoma 180 murine tumor models. Cancer Res 1978;38:345-53.

20. Munno I, Pellegrino NM, Marcuccio C, De Simone C, Jirillo E. Influence of ST 789 on interleukin-1. interleukin-2 and interferon-gamma production from normal human peripheral blood mononuclear cells. Thymus 1992; 19:563-9.

21. Ruggiero V, Albertoni C, Manganello S, Foresta P, Arrigoni Martelli E. Modulation of splenic lymphocyte activities by a new hypoxanthine derivative (ST 789) in immunosuppressed mice. Agents Act 1991;32:171-8.

22. Matsumoto M, Matsubara S, Matsuno T, et al. Protective effect of human granulocyte colony-stimulating factor on microbial infections in neutropenic mice. Infect Immunol 1987;55:2715-22.

23. Hirano T, Akira S, Taga T, Kishimoto T. Biological and clinical aspects of interleukin 6. Immunol Today 1990; 11:443-9.

24. Fong Y, Lowry SF. Tumor necrosis factor in the pathophysiology of infection and sepsis. Clin Immunol Immunopathol 1990;55: 157-70.

25. Fong Y, Marano MA, Moldawer LL, et al. Splanchnic monokine and metabolic response to endotoxin in man. Surg Forum 1988;39:21-3.

26. Fong Y, Moldawer LL, Marano M, et al. Endotoxemia elicits increased circulating IFN/IL-6 in man. J Immunol 1989;142:2321-4.

27. Fong Y, Tracey KJ, Moldawer LL, et al. Antibodies to cachectin/TNF reduces interleukin-1 and interleukin-6 appearance during lethal bacteremia. J Exp Med 1989;170:1627-33. 


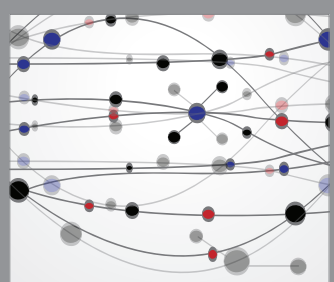

The Scientific World Journal
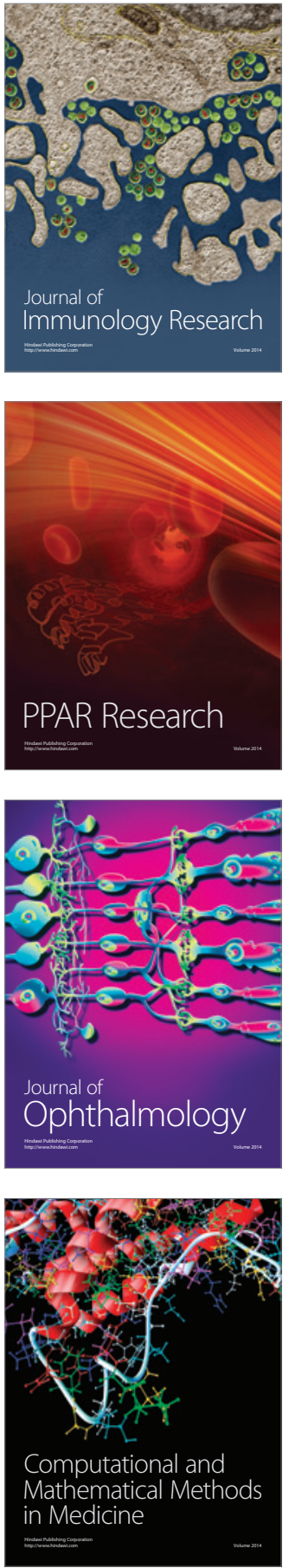

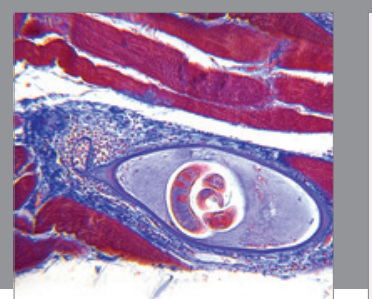

Gastroenterology Research and Practice

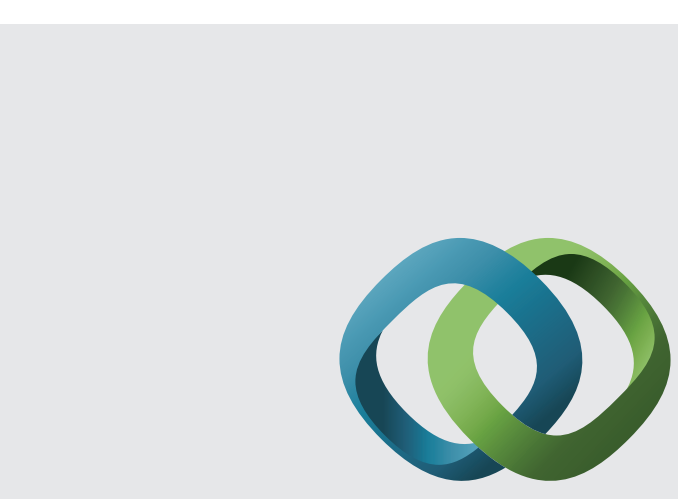

\section{Hindawi}

Submit your manuscripts at

http://www.hindawi.com
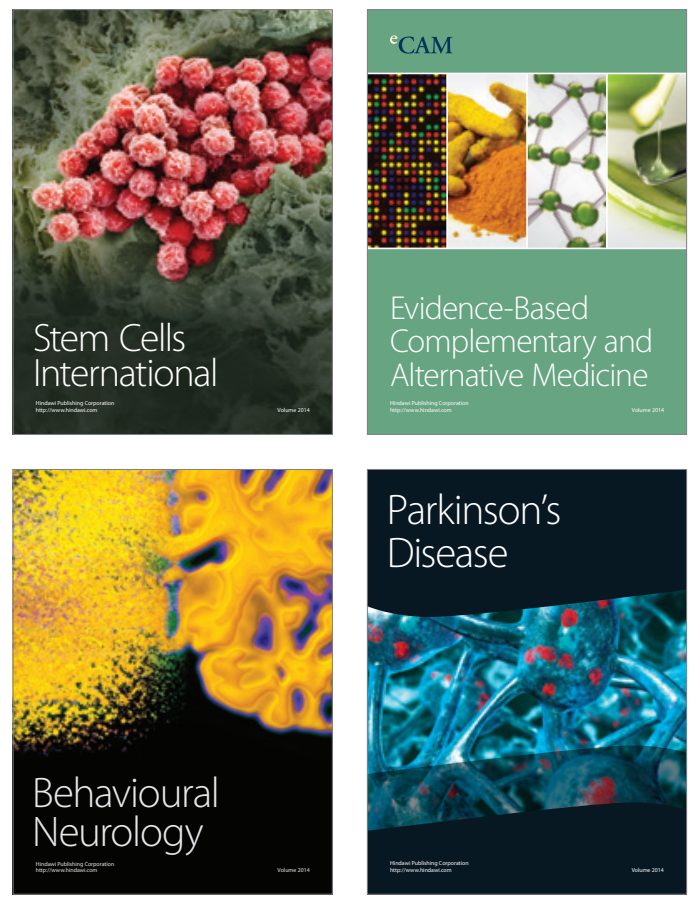
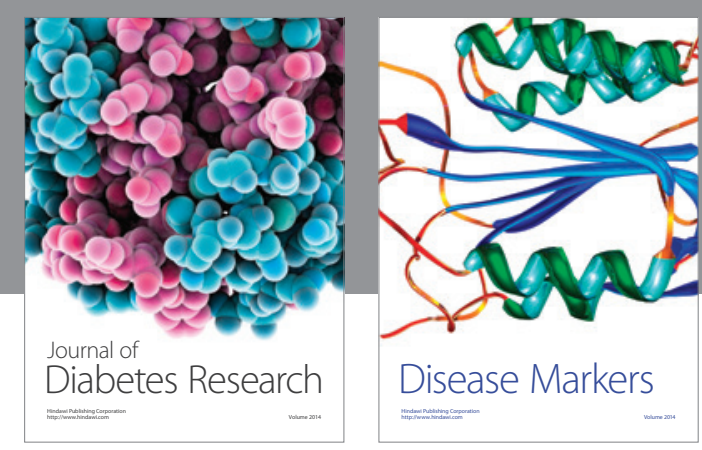

Disease Markers
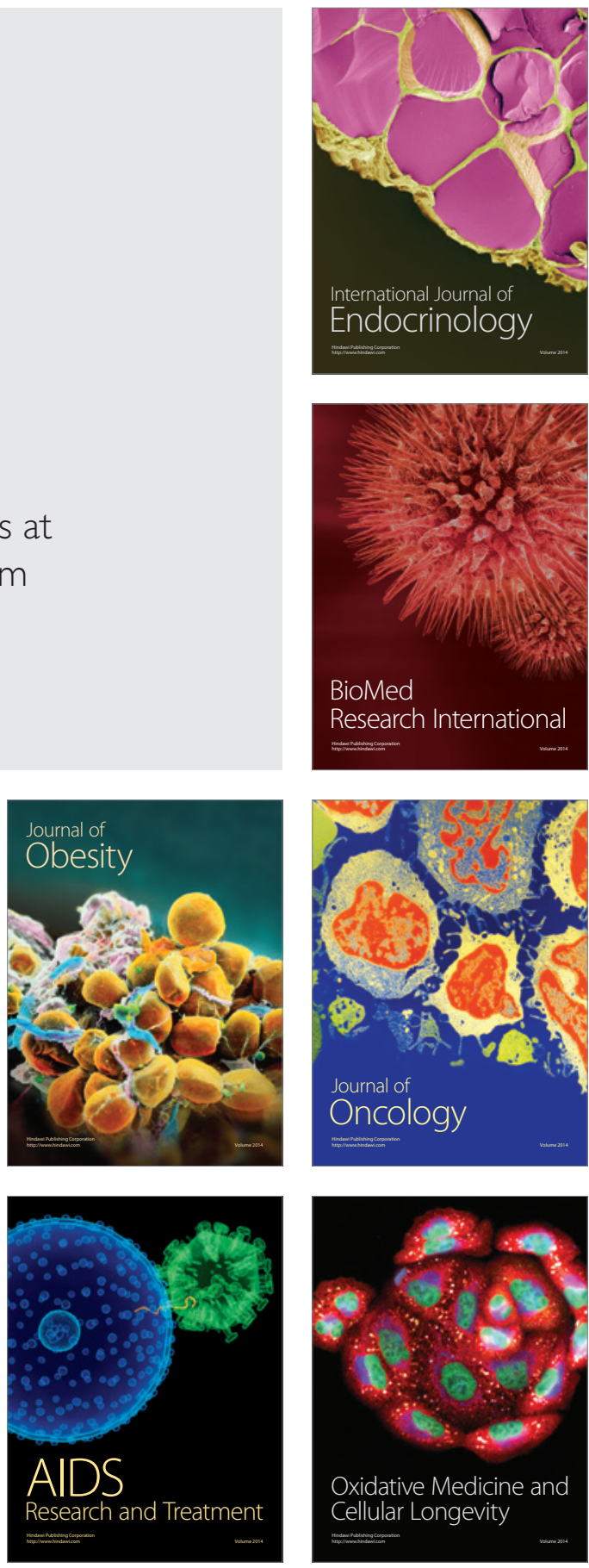